\title{
PTGER4 wt Allele
}

National Cancer Institute

\section{Source}

National Cancer Institute. PT GER4 wt Allele. NCI Thesaurus. Code C128186.

Human PT GER4 wild-type allele is located in the vicinity of 5p13.1 and is approximately 62 $\mathrm{kb}$ in length. This allele, which encodes prostaglandin E2 receptor EP4 subtype protein, is involved in prostaglandin-mediated G protein-coupled receptor signaling. 